\title{
Physical and morphological characteristics of Kankrej bull semen
}

\author{
Bharatkumar R. Patel and G. M. Siddiquee \\ Department of Clinics \\ College of Veterinary Science and Animal Husbandry, \\ Sardar Krushinagar Dantiwada Agricultural University, Sardar Krushinagar-385 506, Gujarat, India \\ Corresponding author: Bharatkumar R. Patel, email: brpatel35@gmail.com, Cell: +919429848703 \\ Received: 09-12-2013, Accepted: 15-01-2013, Published online: 18-04-2013
}

\section{How to cite this article:}

Patel BR and Siddiquee GM (2013) Physical and morphological characteristics of Kankrej bull semen, Vet World 6(7):405408, doi: 10.5455/vetworld.2013.405-408

\begin{abstract}
Aim: Present investigation was carried out to study the physical characteristics of Kankrej bulls semen by evaluation of various semen parameters from neat semen and at various stages of semen preservation.

Materials and Methods: A total of 60 ejaculates, 10 each from 6 mature Kankrej bulls, once in a week for 10 weeks, were collected and analyzed for various semen attributes.

Result: The mean values for different seminal attributes were: ejaculate volume $4.84 \pm 0.01 \mathrm{ml}, \mathrm{pH} 6.88 \pm 0.01$, mass motility $3.72 \pm 0.02$, sperm concentration $1253.83 \pm 14.68$ million / ml, individual motility $86.15 \pm 0.30$ per cent, live sperm count $90.58 \pm 0.20$ per cent, abnormal sperm count $4.24 \pm 0.03$ per cent and acrosomal integrity $81.17 \pm 0.11$ per cent. The colour of the Kankrej bull semen under the investigation was creamy white. Mean values of ejaculate volume, sperm concentration, live sperm count and acrosomal integrity of semen differed significantly $(\mathrm{P}<0.05)$ among the bulls under investigation. The ejaculate volume was positively correlated with mass motility $(+0.392)$ and sperm concentration $(+0.385)$ and inversely proportional to the mass motility whereas mass motility positively correlated with volume $(+0.392)$, individual sperm motility (+0.329) and live sperm count (+0.527).
\end{abstract}

Conclusion: It can be concluded that the volume, $\mathrm{pH}$, mass motility and sperm concentration of Kankrej bull semen were well comparable with other breeds of Indian cattle, however higher individual motility, live sperm count, acrosomal integrity and lower abnormal sperm count were recorded in the Kankrej bull semen.

Keywords: Kankrej bull, physical characteristics, semen, spermatozoal morphology

\section{I ntroduction}

Kankrej cattle is an important dual purpose breed of India. They have well adopted in North Gujarat and developed as elite from Kankrej breed at Livestock Research Station, SDAU, Sardarkrushinagar and proved to be superior to crossbreds with respect to milk production and disease resistance [1]. The main purpose of research in the laboratory evaluation of semen, either fresh or frozen thawed, has been ultimately to predict its fertility. It is well established that characteristics of bull semen vary widely, not only between the bulls, but also between the ejaculates within bulls and from time to time or season to season [2]. Semen volume, concentration of spermatozoa, proportion of dead and abnormal spermatozoa, and motility of spermatozoa are recognized as important indices of semen quality and significantly correlated with freezability and/or fertility of bovine semen [3]. Semen producing ability and quality of individual bull are essentials to ensure the supply of superior quality germplasm for maintaining the production performance in future progeny of individual breed in the country. The interrelationship established through

This article is an open access article licensed under the terms of the Creative Commons Attribution License (http://creativecommons. org/licenses/by/2.0) which permits unrestricted use, distribution and reproduction in any medium, provided the work is properly cited. correlation matrix between various spermatozoal traits at initial, prefreeze and post thawed stages was found highly significant $(P<0.01)$ and positive interrelationships for the percentage of motile spermatozoa, live sperm, abnormal sperm and intact acrosome in fresh, post refrigerated and post thawed semen $(r=0.17$ to 0.90 ) and suggested that these traits could be applied for practical utility in routine semen evaluation to predict keeping quality, freezability and fertility [4]. Genetically an improvement of Kankrej breed was taken up through cryopreservation of male germplasm had good production performance and fertility index.

\section{Materials and Methods}

Climate and Experimental animal: Geographically, Dama is situated at $24^{\circ}-10^{\prime}$ North latitude and $72^{\circ}-10^{\prime}$ East latitude at an altitude of 154.52 meter above the mean sea level. The climate is harsh and the ambient summer temperature goes up to $45^{\circ} \mathrm{C}$ while winter temperature runs down to $3.5^{\circ} \mathrm{C}$. The rains are highly irregular and drought is common. In this study, six Kankrej bulls, ranging from 3 to $4 \frac{1}{2}$ years of age and clinically normal, were selected as semen donors from Dama semen production Unit (Grade-A Semen Collection Unit), Banas dairy, Palanpur. All the standard procedures for semen collection and their evaluation were followed in strict aseptic condition. 
Table-1. Physical and morphological characteristics of neat Kankrej bulls semen (Mean \pm SE)

\begin{tabular}{lllllllll}
\hline Bull no. & Volume $(\mathbf{m l})$ & $\mathbf{p H}$ & $\begin{array}{l}\text { Mass Motility } \\
\text { (0-5 scale) }\end{array}$ & $\begin{array}{l}\text { Sperm } \\
\text { Concentration } \\
\text { Million/ml }\end{array}$ & $\begin{array}{l}\text { Individual } \\
\text { Motility } \\
\text { (percent) }\end{array}$ & $\begin{array}{l}\text { Live Sperm } \\
\text { (percent) }\end{array}$ & $\begin{array}{l}\text { Abnormal } \\
\text { Sperm } \\
\text { (percent) }\end{array}$ & $\begin{array}{l}\text { Acrosomal } \\
\text { Integrity }\end{array}$ \\
\hline $\mathrm{K} 12(\mathrm{n}=10)$ & $4.79 \pm 0.20^{\mathrm{ab}}$ & $6.84 \pm 0.05$ & $3.63 \pm 0.09$ & $1304.5 \pm 23.86^{\mathrm{a}}$ & $84.87 \pm 0.90$ & $91.33 \pm 0.41^{\mathrm{bc}}$ & $5.72 \pm 0.29$ & $87.82 \pm 1.17^{\mathrm{d}}$ \\
$\mathrm{K} 17(\mathrm{n}=10)$ & $4.86 \pm 0.13^{\mathrm{ab}}$ & $6.91 \pm 0.06$ & $3.87 \pm 0.13$ & $1247.0 \pm 21.78^{\mathrm{abc}}$ & $93.95 \pm 0.79$ & $93.22 \pm 0.67^{\mathrm{cb}}$ & $3.42 \pm 0.17$ & $79.82 \pm 1.11^{\mathrm{a}}$ \\
$\mathrm{K} 18(\mathrm{n}=10)$ & $4.73 \pm 0.26^{\mathrm{a}}$ & $6.87 \pm 0.06$ & $3.79 \pm 0.11$ & $1260.0 \pm 23.05^{\mathrm{ac}}$ & $89.67 \pm 1.13$ & $87.54 \pm 0.97^{\mathrm{a}}$ & $4.15 \pm 0.25$ & $86.14 \pm 0.78^{\mathrm{c}}$ \\
$\mathrm{K} 21(\mathrm{n}=10)$ & $4.69 \pm 0.13^{\mathrm{a}}$ & $6.89 \pm 0.04$ & $3.72 \pm 0.13$ & $1265.0 \pm 27.92^{\mathrm{ca}}$ & $86.51 \pm 1.13$ & $89.04 \pm 0.68^{\mathrm{a}}$ & $5.48 \pm 0.36$ & $78.82 \pm 1.29^{\mathrm{a}}$ \\
$\mathrm{K} 23(\mathrm{n}=10)$ & $4.97 \pm 0.17^{\mathrm{b}}$ & $6.93 \pm 0.04$ & $3.92 \pm 0.13$ & $1237.0 \pm 18.32^{\mathrm{b}}$ & $85.57 \pm 0.90$ & $90.17 \pm 0.74^{\mathrm{ab}}$ & $3.20 \pm 0.21$ & $84.82 \pm 1.33^{\mathrm{c}}$ \\
$\mathrm{K} 24(\mathrm{n}=10)$ & $4.98 \pm 0.13^{\mathrm{b}}$ & $6.87 \pm 0.09$ & $3.98 \pm 0.13$ & $1215.0 \pm 31.62^{\mathrm{b}}$ & $79.24 \pm 1.00$ & $92.20 \pm 0.83^{\mathrm{b}}$ & $3.75 \pm 0.24$ & $81.82 \pm 1.36^{\mathrm{b}}$ \\
$\begin{array}{l}\text { Overall Mean } \\
\text { (n=60) }\end{array}$ & $4.84 \pm 0.01$ & $6.88 \pm 0.01$ & $3.72 \pm 0.02$ & $1253.83 \pm 14.68$ & $86.15 \pm 0.30$ & $90.58 \pm 0.20$ & $4.24 \pm 0.03$ & $81.71 \pm 0.11$ \\
\hline
\end{tabular}

* Means with different superscripts within column differ significantly at $5 \%$ level.

Total ten ejaculates were obtained by artificial vagina method from each bull for ten weeks [5].

Semen collection and evaluation: Each ejaculate of neat semen was evaluated immediately after collection for volume, colour, hydrogen ion concentration $(\mathrm{pH})$, mass motility and sperm concentration. Colour of semen was graded as creamy, milky, watery and abnormal and $\mathrm{pH}$ was recorded with the help of $\mathrm{pH}$ indicator paper [5]. The mass motility of semen was recorded by placing a small drop of neat semen on glass slide without coverslip under low magnification (10 X) and graded from 0 to 5 grades [6]. Sperm concentration per $\mathrm{ml}$ of semen was estimated using bovine photometer (Developed by Hamilton Company, IMV, France). The Individual motility of semen was assessed, after covering the semen drop with cover glass, under high magnification (45X).

Live and abnormal sperm counts were assessed by differential staining technique as described by [7] and eosin - nigrosin stain was used as per the procedure of [7]. For staining, proportion of stain and semen was kept as 6 drops: 1 drop respectively. The uniform thin smears were prepared immediately on clean grease free slides. A total of 200 spermatozoa were counted from stained slides using 100X (oil immersion) objective of the microscope (MSP (Give full name) guideline, Govt. of India).

The damage to the acrosome due to deep freezing/preservation/ was determined by staining the slides with Giemsa stain and the pink stained acrosomes were studied for their integrity. A total of 300 spermatozoa with an intact acrosome were counted and calculated according to [8].

Statistical analysis: The means and standard errors of all the traits were calculated using 60 observation (10 ejaculates $\times 6$ bulls) using completely randomized design (CRD) at $P<0.05$ level of significance. The correlation coefficients were worked out based on bullwise means for each of seminal characteristics. The analysis of variance and correlation coefficients between the seminal characteristics were worked out as per the standard procedure described by Snedecor and Cochran [9].

\section{Results and Discussion}

Ejaculate volume, colour and pH of semen: The volume of six Kankrej bulls semen ranged between 3.50 to 5.90 $\mathrm{ml}$ with mean value of $4.84 \pm 0.01 \mathrm{ml}$ (Table-1). The ejaculate volume was found to be significantly $(P<$ 0.05 ) different among the bulls and positively correlated with mass motility $(+0.392)$ and sperm concentration $(+0.385)$. Ejaculate volume were corroborated with reports of [10] in HF bulls, [11] in Jersey bulls, [12,13] in Gir bulls. However [14] in Jersey bulls had recorded higher ejaculate volume as compared to present study whereas [3] in Jersey bulls had recorded lower ejaculate volume.

The colour of the semen was found to be creamy white in all the samples which were similar to [15] in mixed Sahiwal $\times$ Zebu bulls and [3] in Jersey bulls. Varying from creamy colour about 10 per cent of bulls produce yellowish colour of semen which might be due to lipochrome pigment derived from the epithelium of ampulla during seminal secretion and considered as normal colour, harmless to sperm cell and no way influences the fertility of the bull. The mean $\mathrm{pH}$ value of six Kankrej bulls semen was $6.88+0.01$ (Table-1) which was comparable with those of [16] in exotic cow bulls. They opined that higher $\mathrm{pH}$ of the semen was neutralized by various vaginal acids, which were secreted from vaginal mucus glands.

Mass motility and sperm concentration: Mass motility of sperms has been an important attribute for acceptance or rejection of the ejaculate for further processing and use in AI, and it has been positively correlated with keeping quality, freezability and fertility of that sample [4]. In present study mass motility of six Kankrej bulls semen was significantly $(P<0.05)$ and positively correlated with volume $(+0.392)$, individual sperm motility $(+0.329)$ and live sperm count $(+0.527)$. Mass motility of semen was observed between +3 to +5 with mean value of $3.72 \pm$ 0.02 (Table-1) and it was in harmony with the observations of [13] in Gir bulls and [17] in Friesian x Sahiwal bulls.

The sperm concentration per $\mathrm{ml}$ of semen of Kankrej bulls was recorded as $1253.83 \pm 14.68$ (Table 1) million with a range of 1144 to 1480 million per ml. Sperm concentration was significantly $(P<0.05)$ different among the bulls and inversely proportional to the ejaculate volume of semen. The mean values of sperm concentration recorded in present study were in 
Table-2. Vital count of spermatozoa during different stages of freezing process

\begin{tabular}{llll}
\hline Morphology & Postdiluted & Postequilibrated & Post thawed \\
\hline Individual Motility (\%) & $80.59 \pm 0.43^{\mathrm{a}}$ & $74.73 \pm 0.58^{\mathrm{b}}$ & $56.83 \pm 0.34^{\mathrm{c}}$ \\
Live Sperm (\%) & $87.24 \pm 0.44^{\mathrm{a}}$ & $79.91 \pm 0.24^{\mathrm{b}}$ & $58.22 \pm 0.24^{\mathrm{c}}$ \\
Abnormal Sperm (\%) & $6.13 \pm 0.07^{\mathrm{a}}$ & $7.56 \pm 0.15^{\mathrm{b}}$ & $13.52 \pm 0.35^{\mathrm{c}}$ \\
Acrosomal Integrity (\%) & $75.13 \pm 0.42^{\mathrm{a}}$ & $68.16 \pm 0.80^{\mathrm{b}}$ & $53.65 \pm 0.58^{\mathrm{c}}$ \\
\hline
\end{tabular}

* Means with different superscripts within column differ significantly at $1 \%$ level.

agreement with reports of [14] in Jersey bulls, [12] in Gir bulls, [18] in Sahiwal bulls and [15] in mixed breed bulls.

Individual motility and live sperm count: The individual motility of Kankrej bull semen ranged between 80 to 92 per cent with the mean values of 86.15 \pm 0.30 per cent (Table-1). Individual motility of spermatozoa in present study was at par with reports of $[10,19]$ in HF bulls, [11] in Sahiwal and Jersey bulls. The wide variation in the ejaculate volume, mass motility, sperm concentration and individual motility has been attributed to various factors like age of bull, season, frequency of collection [6], degree of sexual excitement, method of semen collection, etc. [20].

The percentage of live sperm was significantly $(P$ $<0.05)$ differed among bulls and positively correlated with individual sperm motility $(+0.702)$. Live sperm in Kankrej bull semen ranged between 81 to 94 per cent. Overall mean value of live sperm count $90.58 \pm 0.20$ per cent (Table-1) with no significant difference among bulls. Similar percentage of live sperm count were recorded by [11] in Sahiwal bulls, [12] in Gir bulls and [14] in Jersey bulls recorded. The variation in live sperm count has been attributed to frequency of collection [6], age of breeding bull and season [11].

Abnormality and Acrosomal integrity of spermatozoa: Abnormal spermatozoa affect the fertility of male. The admissible limit of abnormal spermatozoa has been less than 10 per cent in normal semen which could be utilized for fertilization [3]. Conventionally semen with more than 20 per cent abnormal sperm must be discarded [16]. Abnormal sperm count in Kankrej bull semen was statistically non significant among bulls. The mean value was $4.24 \pm 0.11$ per cent (Table 1 ), which ranged between 3 to 9 per cent. In the present study abnormal sperm count in semen was in close agreement with those reported by [21] in Kankrej $\mathrm{x}$ Jersey bulls, [22] in Punganur bulls and [3] in Jersey bulls.

The presence of an acrosomal cap is important in the fertilization process and highly related with fertility of frozen semen. Intact apical ridge of acrosome is necessary for fertilizing capacity of spermatozoa and for functional efficiency of the acrosome. However, some spermatozoa could be highly motile but not fertile, owing to the acrosomal damage [2]. Mean acrosomal integrity of six Kankrej bulls semen differed significantly $(P<0.05)$ among the bulls under investigation. The mean value of sperms with intact acrosome in Kankrej bulls was recorded as $81.17 \pm$ 0.11 per cent (Table-1), which ranged between 79 to 88 .
Detatchment of acrosome or loss of acrosomal intactness may result in to decreased ATP. The acrosomal cap undergoes changes in biochemical composition and ultra-structure during fertilization. Acrosomal enzymes play a key role during sperm penetration in zona pellucida. The percentage of sperms which had intact acrosome in present study was similar to those reported by [23] in Gir bulls and [14] in Jersey crossbred bulls. However, contrary to the present findings some workers reported lower intact acrosome sperm count in HF bulls while others[13] in elite ethiopian indigenous breed bulls and [17] in Sahiwal bulls, recorded higher acrosomal integrity of sperms as compared to present study.

Vital count of spermatozoa during different stages of freezing process: Individual motility, live sperm count and acrosomal integrity were significantly $(P<0.01)$ decreased and abnormal sperm count was significantly $(P<0.01)$ increased as freezing process progressed, as at post diluted stage it was $80.59 \pm 0.43,87.24 \pm 0.44$, $6.13 \pm 0.07$ and $75.13 \pm 0.42$ per cent, respectively, whereas at post equilibrated stage it was $74.73 \pm 0.58$, $79.91 \pm 0.24,7.56 \pm 0.15$ and $68.16 \pm 0.80$ per cent and it was $56.83 \pm 0.34,58.22 \pm 0.24,13.52 \pm 0.35$ and $53.65 \pm 0.58$, respectively at post thawed stage of semen preservation (Table-2). In accordance to present investigation [19] in Jersey bulls and crossbred bulls [11] in Sahiwal bulls and [23] in Gir bulls; reported that individual sperm motility, live sperm count and acrosomal integrity were significantly $(P<0.01)$ dropped, whereas percentage of abnormal sperm count was significantly $(P<0.01)$ increased following freezing of semen.

\section{Conclusion}

In conclusion, ejaculate volume, $\mathrm{pH}$, mass motility and sperm concentration of Kankrej bull semen were well comparable with other breeds of Indian cattle, however higher individual motility, live sperm count, acrosomal integrity and lower abnormal sperm count were recorded in the Kankrej bull semen. The individual sperm motility, live sperm count and acrosomal integrity were significantly decreased where as abnormal sperm count was significantly increased at freezing process progressed.

\section{Authors' contribution}

BR planned and carried out the research work and analyzed the data. BR and GM drafted and revised the manuscript. Both author read and approved the final manuscript. 


\section{Acknowledgements}

Authors are thankful to Dama semen production Unit, Banas dairy, Palanpur and Dean, College of Veterinary Science and Animal Husbandry, SDAU, India, for providing necessary facilities during research work of first author and analysis of the semen samples.

\section{Competing interests}

Author declare that they have no competing interest.

\section{References}

1. Annual progress Report. (2009) Livestock Research Station, SDAU, Sardarkrushinagar, Banaskatha (District), Gujarat.

2. Raval, R. J. and Dhami, A. J. (2010) Effect of additives on various spermatozoal attributes of fresh, Frozen-thawed and refrigerated semen. Indian J. Anim. Reprod., 31(1): 33-36.

3. Fiaz, M., Usmani, R. H., Abdullah, M. and Ahmad, T. (2010) Evaluation of Semen Quality of Holstein Friesian and Jersey Bulls Maintained under Subtropical Enviroment. Pak. Vet.J., 30(2): 75-78.

4. Bhoite U. Y., Sutar, D. A. and Ulmek, B. R. (2005) Effect of season and period on semen characteristics of two and three breed Gir crosses. Indian J. Anim. Reprod., 26(1): 43-45.

5. Saxena, M. S. (2000) Veterinary Andrology and Artificial Insemination. CBS Publishers and Distributors, New Delhi, pp. 89-94.

6. Tomar, N. S. (1984) Artificial Insemination and Reproduction of Cattle and Buffalo. $3^{\text {rd }}$ Edn. Saroj Prakashan, Allahabad.

7. Hancock, J. L. (1951) The morphology of Bull spermatozoa. J. Exp. Biol., 29: 445-453.

8. Watson, P. F. (1975) Use of Giemsa stain to detect changes in the acrosome of frozen ram spermatozoa. Vet. Rec., 97: 1215.

9. Snedecor, G. W. and Cochran, W. G. (1994) Statistical methods. $8^{\text {th }}$ Edn. Affiliated East-West Press, New Delhi, India.

10. Patel, K. V., Dhami, A. J., Chauhan, M. K., Dave, A. S., Vadodaria, V. P. and Dugwekar, Y. G. (2000) Freezability, enzyme leakage and fertility of bovine spermatozoa. Indian J. Dairy Sci., 53(4): 284-290.

11. Singh, S. P., Pandit, R. K. and Bhadoriya, H. B. S. (2000) Sexual behaviour and seminal characteristics in Jersey,
Sahiwal and halfbred bulls. Indian J. Anim. Sci., 70(3): 279280.

12. Shelke, V. B. and Dhami, A. J. (2001) Comparative evaluation of physicomorphological of buffalo semen extende in CAW extender. $I I^{\text {nd }}$ World Buffalo Congress, New Delhi, India, Proceedings. 3: 89-93.

13. Sori, H., Prasad, S. and Zewdie, E. (2006) Seminal characterization of some elite Ethiopian indigenous breeds of bull. Indian J. Anim. Reprod., 27 (2): 54-60.

14. Perumal, P., Barik, A. K., Mohanty, D. N., Das, R. K. and Mishra, P. C. (2009) Seminal characteristics of Jersey crossbred bulls. In. Proc. XXV th annual convention of the indian society for study of animal reproduction and international symposium. pp. 196.

15. Shaha, S. P., Alam, M. G. S., Khatun, M. and Ahmed, J. U. (2008) Breeding soundness of stud bulls. The Bangladesh Vet.J., 25(2): 51-61.

16. Roberts, S. J. (1986) Veterinary Obstetrics and Genital Diseases. $3^{\text {rd }}$ Edn. Stephen Roberts, Woodstock, VT, USA, pp. 622, 709 .

17. Andrabi, S. M., Naheed, S., Khan, L. A. and Ullah, N. (2002) Semen characteristics of crossbred bulls at livestock research station. Pakistan Vet. J., 22(4): 181-187.

18. Mandal, D. K., Tyagi, S. and Mathur, A. K. (2005) Semen production performance of Sahiwal bulls. Indian J. Anim. Sci., 75(1): 17-19.

19. Dhami, A. J., Mohan, G. and Sahni, K. L. (1998) Seasonal influence on the quality and freezability of semen of Friesian and Murrah buffalo bulls. Indian J. Anim. Reprod., 19(1): 5558.

20. Koivisto, M. B., Costa, M. T., Perri, S. H. and Vicente, W. R. (2008) The Effect of Season on Semen Characteristics and Freezability in Bos indicus and Bos taurus Bulls in the Southeastern Region of Brazil. Reprod. Dom. Anim., 10: 1439-1531.

21. Patel, B. R. and Siddiquee, G. M. (2012) Effect of semen diluent additives on spermatozoal viability of Kankrej bull semen following cryopreservation. Wayamba Journal of Animal Science, Article no. 1343241546.

22. Baburao, K., Naidu, V., Singh, V., Seshagiri, R. A. and Suresh, J. (1999) Studies on semen characteristics of Punganur bulls. Indian Vet. J., 76: 35-37.

23. Rana, C. M. and Dhami, A. J. (2004) Physical attributes intact acrosome, HOST and Freezability of Semen of Gir and Jafarabadi bulls. Indian Vet. J., 81: 406-410. 